\title{
Fungitoxic Compounds from the Roots of Tomato Stock
}

\author{
Toshinori NAGAOKA*, Junko OHRA**, Teruhiko YOSHIHARA** \\ and Sadao SAKAMURA**
}

\begin{abstract}
Fungitoxic compounds from the roots of tomato stocks, Taibyo Shinko No. 1, were determined as four unsaturated hydroxy fatty acids $[(13 S)$-13-hydroxy-(9Z,11E)-9,11-octadecadienoic acid, 13-hydroxy$(9 E, 11 E)$-9,11-octadecadienoic acid, $(9 S)$-9-hydroxy-(10E,12Z)-10,12-octadecadienoic acid and 9-hydroxy$(10 E, 12 E)$-10,12-octadecadienoic acid], a dicarboxylic acid (azelaic acid), a quinone (2,6-dimethoxy- $p$ benzoquinone) and five phenolic compounds (vanillin, syringaldehyde, $p$-hydroxybenzaldehyde, $p$ hydroxybenzoic acid, vanillic acid). It can be considered that the fungitoxic compounds related to resistance of the tomato stock against soil-borne disease were alkaloids, but not these universal compounds in plants.
\end{abstract}

(Received July 14, 1994 ; Accepted October 13, 1994)

Key words : tomato stock, soil-born disease, fungitoxic compounds.

\section{INTRODUCTION}

Solanaceous plants have been avoided from successive cultivation on the same fields for several years as their yields decrease without rotation of crops. This phenomenon is mostly caused by pathogens of soil-borne diseases. Grafting is one of the good methods for successive cultivation on the same fields. Generally, wild relatives or hybrids between wild and cultivated plants have been employed as stocks. In a previous paper ${ }^{10)}$ we have reported the fungitoxic compounds from the roots of a eggplant stock, Taibyo VF, and concluded that sesquiterpenes, especially solavetivone ${ }^{1)}$, played important parts in resistance of the plant. Taibyo Shinko No. 1, one of the tomato stocks, is a hybrid between Lycopersicon esculentum and L. hirsutum var. glabratum, and highly resistant against Fusarium oxysporum f. sp. lycopersici, F. oxysporum f. sp. radicis-lycopersici, Verticillium dahliae and Pyrenochaeta lycopersici. This report deals with the fungitoxic compounds from the roots of Taibyo Shinko No. 1 to investigate the resistant mechanisms of tomato stock against the soil-borne diseases from the standpoint of chemical substances of plants.

\section{MATERIALS AND METHODS}

Plants. Stocks (L. esculentum $\times$ L. hirsutum var. glabratum, Taibyo Shinko No. 1) and tomatoes ( $L$. esculentum, cultivar Kyoryoku Beiju) were grown in the greenhouse for two months and transferred to the field.
The three-month-old plants after transplantation were harvested.

Bioassay. The following fungi were used for bioassay of fungitoxic activity of ether, ethyl acetate and water soluble substances: Fusarium oxysporum f. sp. lycopersici, F. oxysporum f. sp. radicis-lycopersici, Verticillium dahliae and Pyrenochaeta lycopersici. The extracts $(7.5 \mathrm{mg})$ dissolved in $0.15 \mathrm{ml}$ of $50 \%$ EtOH- $\mathrm{H}_{2} \mathrm{O}$ were mixed with PDA medium $(15 \mathrm{ml})$ in test tubes and then transferred to petri dishes. Mycelial blocks were excised from the medium with a cork borer in $7 \mathrm{~mm}$ diameter and put on the medium containing extracts. They were incubated at $23^{\circ} \mathrm{C}$ during one week for $F$. oxysporum f. sp. lycopersici, $F$. oxysporum f. sp. radicis-lycopersici and P. lycopersici and three weeks for $V$. dahliae.

A bioautographic technique according to Homans and Fuchs $^{3)}$ was used for detection of fungitoxic compounds. Cladosporium herbarum instead of four pathogens was used to monitor the fungitoxic compounds during the separation processes.

The antifungal activities of seven alkaloids ${ }^{7)}$, (25S)$5 \alpha, 22 \beta \mathrm{N}$-spirosolan- $3 \beta$-ol (1, tomatidine), $\quad(25 S)-5 \alpha$, $22 \beta \mathrm{N}$-spirosolan-3-one (2, $5 \alpha$-tomatidan-3-one), $(23 R$, $25 S)$-23-acetoxy- $5 \alpha, 22 \beta \mathrm{N}$-spirosolan-3 $\beta$-ol [3, (23R)-23acetoxytomatidine ], $(23 S, 25 R)$-23-acetoxy- $5 \alpha, 22 \alpha \mathrm{N}$ spirosolan-3 $\beta$-ol $\quad[4, \quad(23 S)-23$-acetoxysoladulcidine $]$, (23S,25S)-23-acetoxy- $5 \alpha, 22 \alpha \mathrm{N}$-spirosolan-3 $\beta$-ol (5), 22 , 26 -epimino- $16 \beta, 23$-epoxy-23 $\alpha$-ethoxy- $5 \alpha, 25 \alpha \mathrm{H}$-cholest$22(\mathrm{~N})$-ene-3 $\beta, 20 \alpha$-diol (6) and 22,26-epimino-16 $\beta, 23$ epoxy- $5 \alpha, 22 \beta \mathrm{H}, 25 \alpha \mathrm{H}$-cholestane- $3 \beta, 23 \alpha$-diol (7), from the stock were evaluated by means of a TLC plate

\footnotetext{
* Faculty of Applied Biological Science, Hiroshima University, Kagamiyama 1-4-4, Higashihiroshima 724, Japan 広島 大学生物生産学部

** Department of Bioscience and Chemistry, Faculty of Agriculture, Hokkaido University, Kita-ku, Sapporo 060, Japan 北海道大学農学部
} 
bioassay. The spores of $F$. oxysporum f. sp. radicislycopersici in culture solution ${ }^{3)}$ were sprayed on silica gel TLC plate (Merk 9385, $0.5 \mathrm{~mm}$ ), on which the alkaloids at the amount of $1,5,10,20,25,50,100,200$ and $250 \mu \mathrm{g}$ had been added within $5 \mathrm{~mm}$ diameter. After incubation of 1 day in the humid vessel at $20^{\circ} \mathrm{C}$, powder of active carbon was sprinkled on the plate. The white inhibition rings with a black background were observed.

Extraction and separation of fungitoxic compounds. Chopped roots materials $(7.5 \mathrm{~kg})$ were extracted by immersing in $70 \%$ aqueous ethanol (55 liter) after filtration, the extract solutions were evaporated under reduced pressure. The concentrate (1 liter) was extracted with $\mathrm{Et}_{2} \mathrm{O}(1$ liter $\times 3)$ and then EtOAc (1 liter $\times 3)$. The $\mathrm{Et}_{2} \mathrm{O}$, EtOAc and water layers were concentrated respectively under reduced pressure to dryness. The $\mathrm{Et}_{2} \mathrm{O}$ extracts $(10 \mathrm{~g})$ were subjected to column chromatography on silica gel (Wako gel C-200, $150 \mathrm{~g}$ ) and eluted sequentially with $\mathrm{CHCl}_{3}, \mathrm{CHCl}_{3}-\mathrm{MeOH}$ (19: 1), $(9: 1),(4: 1),(7: 3)$ and $\mathrm{MeOH}$ to separate to 13 fractions monitoring with UV absorption at $280 \mathrm{~nm}$. The TLC bioautogram of these fractions showed the presence of fungitoxic compounds in Fr.4-Fr.11 (Fig. 2).

Fr.4 (1.72 g) was chromatographed on silica gel column (Kiesel gel 60, $50 \mathrm{~g}$ ) with EtOAc-hexane (2:8) and an active fraction was separated with preparative TLC to obtain fungitoxic compounds A $(0.8 \mathrm{mg}), \mathrm{B}(0.7 \mathrm{mg})$ and $\mathrm{C}(1.0 \mathrm{mg})$.

Fr.6 (771 mg) was separated with silica gel column (Wako gel C-200, 30 g) chromatography eluted with EtOAc-benzene $(2: 8)$. Active fraction was subjected to preparative TLC to isolate fungitoxic compound D (1.2 mg).

A part of Fr.7 $(126 \mathrm{mg})$ was dissolved in $\mathrm{Et}_{2} \mathrm{O}(30 \mathrm{ml})$ and extracted with $1 \mathrm{~N} \mathrm{NaOH}(30 \mathrm{ml} \times 3)$ to yield $\mathrm{Et}_{2} \mathrm{O}$ layer (neutral and basic substances) and alkaline layer (acidic substances). The $\mathrm{Et}_{2} \mathrm{O}$ layer (neutral and basic substances) was extracted with $1 \mathrm{~N} \mathrm{HCl}(30 \mathrm{ml} \times 3)$ to get $\mathrm{Et}_{2} \mathrm{O}$ layer which was concentrated to dryness (neutral substances, $30 \mathrm{mg}$ ) and acidic layer (basic substances). The acidic layer was adjusted to $\mathrm{pH} 13$ with 1 $\mathrm{N} \mathrm{NaOH}$ and extracted with $\mathrm{Et}_{2} \mathrm{O}(180 \mathrm{ml} \times 3)$ to obtain $\mathrm{Et}_{2} \mathrm{O}$ extracts (basic substances, $34 \mathrm{mg}$ ). The alkaline layer (acidic substances) was adjusted to $\mathrm{pH} 3$ with $1 \mathrm{~N}$ $\mathrm{HCl}$ and extracted with $\mathrm{Et}_{2} \mathrm{O}(180 \mathrm{~m} \times 3)$, which was concentrated under reduced pressure to dryness (acidic substances, $33 \mathrm{mg}$ ). The TLC bioautogram of acidic fraction exhibited strongly inhibiting zone, but the neutral and basic fraction exposed no inhibiting zone. As it was difficult to purify acidic fungitoxic compounds with reverse phase HPLC, acidic fraction was methylated with diazomethane and subjected to normal phase HPLC equipped with $\mu$ Porasil column $(7.8 \mathrm{~mm} \times 30 \mathrm{~cm})$ using EtOH-hexane $(1: 200)$ at $2.2 \mathrm{ml} / \mathrm{min}$ monitoring in $235 \mathrm{~nm}$, resulting in the purification of four methyl esters of fungitoxic compound E (3.9 mg), F (1.8 mg), G (2.7 mg) and $\mathrm{H}(1.2 \mathrm{mg})$.

Fr.8 (2248 mg) was chromatographed on silica gel column (Kiesel gel 60, $120 \mathrm{~g}$ ) and eluted with $\mathrm{Me}_{2} \mathrm{CO}$ $\mathrm{CHCl}_{3}(2: 8)$ to yield two fungitoxic fractions (Fr.8D-8E). Fr.8D was separated to acidic, neutral, basic fraction by liquid-liquid partition and acidic fraction gave two methyl esters of fungitoxic compounds $\mathrm{G}(9.1 \mathrm{mg})$ and $\mathrm{H}$ $(6.3 \mathrm{mg})$ with HPLC after methylation according to the method described in Fr.7. Fr.8E was also fractionated to acidic, neutral and basic fraction. The acidic fraction was separated with HPLC in the same conditions after methylation to obtain two methyl esters of fungitoxic compounds I $(0.7 \mathrm{mg})$ and $\mathrm{J}(2.8 \mathrm{mg})$

Fr.9 was subjected to Sephadex LH-20 $(4.8 \times 33 \mathrm{~cm})$ column and eluted with $\mathrm{MeOH}-\mathrm{CHCl}_{3}(1: 1)$ to get fungitoxic Fr.9C and Fr.9D. Fungitoxic compound I (17 mg) was purified as methyl ester from 9D with preparative TLC using $\mathrm{MeOH}-\mathrm{CHCl}_{3}$ (5:95). Fr.9C was separated with preparative TLC using $\mathrm{MeOH}-\mathrm{CHCl}_{3}(5: 95)$ after methylation and gave fungitoxic compound $\mathrm{K}$ (10.1 mg).

Ether, ethyl acetate and water-soluble content of stock and tomato. Chopped roots $(3.0 \mathrm{~kg})$ of each plants were extracted, and the extracts were partitioned with the listed solvents by the usual way. Ether soluble fraction was separated to three fractions by changing $\mathrm{pH}$.

Quantitative analysis of unsaturated hydroxy fatty acids. Chopped roots materials of stocks and tomatoes $(0.3 \mathrm{~kg})$ were extracted by immersing in $70 \%$ aqueous ethanol (2 liter). The extract solutions after filtration were evaporated under reduced pressure. The concentrate $(100 \mathrm{ml})$ was extracted with $\mathrm{Et}_{2} \mathrm{O}(100 \mathrm{ml} \times$ 3 ) and then EtOAc $(100 \mathrm{ml} \times 3)$. The $\mathrm{Et}_{2} \mathrm{O}$ layers were concentrated and dissolved in $\mathrm{Et}_{2} \mathrm{O}(50 \mathrm{ml})$ and extracted with $1 \mathrm{~N} \mathrm{NaOH}(50 \mathrm{ml} \times 2)$ to yield $\mathrm{Et}_{2} \mathrm{O}$ layer and water layer. Water layer was adjusted to $\mathrm{pH} 3$ with $1 \mathrm{~N} \mathrm{HCl}$ and extracted with $\mathrm{Et}_{2} \mathrm{O}(200 \mathrm{ml} \times 3)$, which was concentrated under reduced pressure to dryness to get the acidic fraction. The acidic fraction was methylated with diazomethane and separated with HPLC equipped with $\mu$ Porasil column $(7.8 \mathrm{~mm} \times 30 \mathrm{~cm})$ using EtOH-hexane ( $1: 200)$ at $2.2 \mathrm{ml} / \mathrm{min}$ monitoring in $235 \mathrm{~nm}$. The separated four unsaturated hydroxy fatty acids were weighed and quantities of four compounds in fresh roots were calculated.

Spectral analysis. UV spectra were recorded on Hitachi Perkin-Elmer 139 UV-VIS and Hitachi ESP-3T spectrophotometers. IR spectra were taken with a Hitachi 285 infrared spectrophotometer. NMR spectra were recorded on JEOL JNM FX-100, JEOL JNM FX-500 and JEOL JNM GX-270 FT-NMR spectrometers. Optical rotations were measured on a JASCO DIP-4 Digital Polarimeter. Mass spectra were obtained with JEOL JMS-D300 Mass spectrometer and JEOL JMS-01SG2 High Resolution Mass Spectrometer.

\section{RESULTS}

\section{Fungitoxic activities of extracts}

$\mathrm{Et}_{2} \mathrm{O}$, EtOAc and water extracts from stocks and 
tomatoes were examined for fungitoxic activities against $F$. oxysporum f. sp. lycopersici, $F$. oxysporum f. sp. radicis-lycopersici, $V$. dahliae and $P$. lycopersici (Fig. 1).

$\mathrm{Et}_{2} \mathrm{O}$ and EtOAc extracts showed strong inhibition against $F$. oxysporum f. sp. lycopersici, $F$. oxysporum f. sp. radicis-lycopersici, and $V$. dahliae more largely in stocks than tomatoes but no inhibition against $P$. lycopersici. Water extracts inhibited growth of $P$. lycopersici, but stimulated growth of $V$. dahliae more strongly in tomatoes than stocks.
Some large inhibiting zones were found in TLC bioautogram of $\mathrm{Et}_{2} \mathrm{O}$ extracts (Fig. 2).

Contents of ether, ethyl acetate and water sol-

\section{uble substances}

The contents were shown in Table 1. The ether soluble substances of stock were less than that of tomato. But the alkaloid component in former was more than that of later.

Identification of compound $A$

Yield $0.11 \mathrm{mg} / \mathrm{kg}$ fresh roots. EI-MS $m / z$ (rel.int.): 152

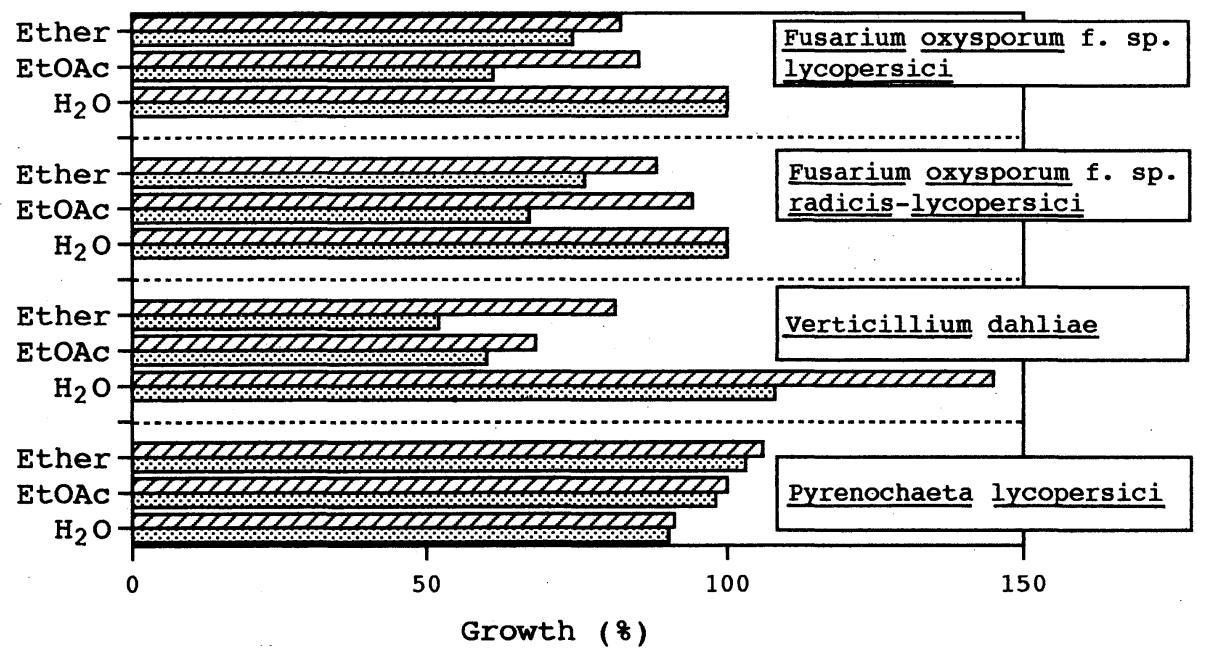

Fig. 1. Fungitoxic activities of extracts from tomato plants (500 ppm). VIII Tomato, 3 Stock.

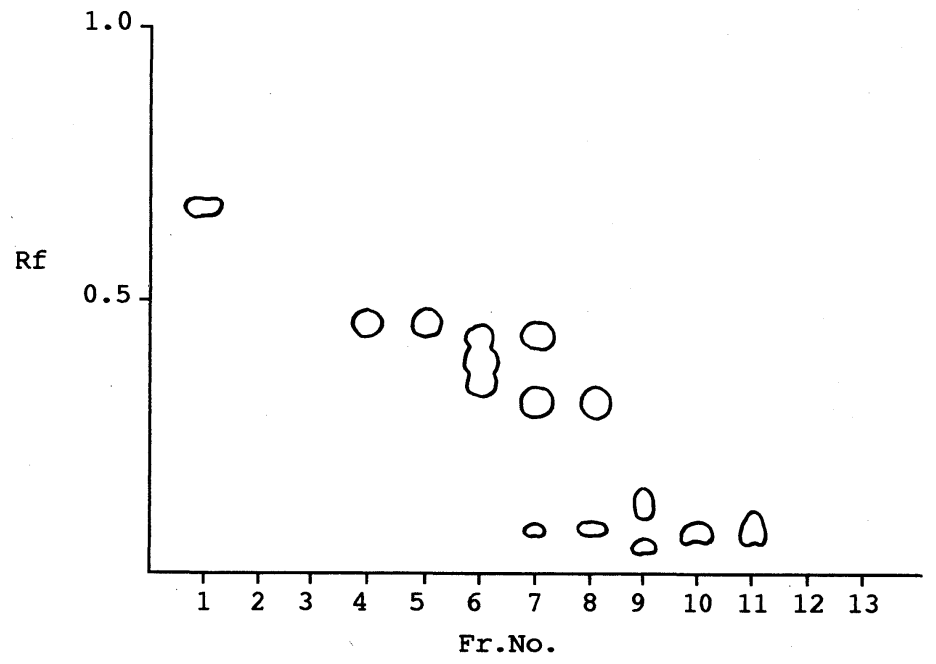

Fig. 2. TLC bioautogram of the fractionated ether extracts of stocks. [C. herbarum, $\left.\mathrm{CH}_{3} \mathrm{OH}-\mathrm{CHCl}_{3}(1: 9 \mathrm{v} / \mathrm{v})\right]$ $\bigcirc$, inhibition zone.

Table 1. Contents of ether, ethyl acetate and water soluble substances (mg/g fresh roots)

\begin{tabular}{|c|c|c|c|c|c|}
\hline & \multicolumn{3}{|c|}{ Ether } & \multirow{2}{*}{ Ethyl acetate } & \multirow{2}{*}{ Water } \\
\hline & Acidic & Neutral & Basic & & \\
\hline \multirow{2}{*}{ Stock } & & 1.56 & & \multirow{2}{*}{0.21} & \multirow{2}{*}{20.1} \\
\hline & 0.63 & 0.45 & 0.25 & & \\
\hline \multirow{2}{*}{ Tomato } & & 1.71 & & \multirow{2}{*}{0.24} & \multirow{2}{*}{11.3} \\
\hline & 0.55 & 0.69 & 0.15 & & \\
\hline
\end{tabular}


$[\mathrm{M}]^{+}(100), 151[\mathrm{M}-\mathrm{H}]+(100), 137(8), 123(22) .{ }^{1} \mathrm{H}-\mathrm{NMR}$ (100 $\left.\mathrm{MHz}, \mathrm{CDCl}_{3}, \mathrm{TMS}\right): \delta 3.97(3 \mathrm{H}, s), 6.17(1 \mathrm{H}, s), 7.04$ $(1 \mathrm{H}, d, J=8.3 \mathrm{~Hz}), 7.42(1 \mathrm{H}, d, J=1.7 \mathrm{~Hz}), 7.43(1 \mathrm{H}, d d$, $J=8.5$ and $1.7 \mathrm{~Hz}), 9.83(1 \mathrm{H}, s)$. Positive to the phenol reagent and 2,4-dinitrophenylhydrazine.

The structure of A was identical with vanillin.

\section{Identification of compound $B$}

Yield $0.09 \mathrm{mg} / \mathrm{kg}$ fresh roots. EI-MS $m / z$ (rel.int.): $182.0597[\mathrm{M}]^{+}\left(\mathrm{C}_{9} \mathrm{H}_{10} \mathrm{O}_{4}\right)(100), 181[\mathrm{M}-\mathrm{H}]^{+}(41), 167$ (12), 153 (3), 139 (9). ${ }^{1} \mathrm{H}-\mathrm{NMR}$ (100 MHz, $\left.\mathrm{CDCl}_{3}, \mathrm{TMS}\right)$ : $\delta 3.97(6 \mathrm{H}, s), 7.15(2 \mathrm{H}, s), 9.81(1 \mathrm{H}, s)$. Positive to the phenol reagent and 2,4-dinitrophenylhydrazine.

These data supported that the structure of $B$ was syringaldehyde.

\section{Identification of compound $C$}

Yield $0.16 \mathrm{mg} / \mathrm{kg}$ fresh root. FD-MS $m / z$ (rel.int.): 168 $[\mathrm{M}]^{+}(100) .{ }^{1} \mathrm{H}-\mathrm{NMR}\left(100 \mathrm{MHz}, \mathrm{CDCl}_{3}, \mathrm{TMS}\right): \delta 3.82(6 \mathrm{H}$, $s), 5.84(2 \mathrm{H}, s)$. IR $\nu_{\max }{ }^{\mathrm{KBr}} \mathrm{cm}^{-1}: 1680,1630,1610,1580$.

The compound $\mathrm{C}$ was identified as 2,6-dimethoxy- $p$ benzoquinone.

\section{Identification of compound $D$}

Yield $0.16 \mathrm{mg} / \mathrm{kg}$ fresh root. EI-MS $m / z$ (rel.int.): 122 $[\mathrm{M}]^{+}(84), 121[\mathrm{M}-\mathrm{H}]^{+}(100), 93$ (45). ${ }^{1} \mathrm{H}-\mathrm{NMR}(100$ $\left.\mathrm{MHz}, \mathrm{CDCl}_{3}, \mathrm{TMS}\right): \delta 6.95(2 \mathrm{H}, d, J=8.5 \mathrm{~Hz}), 7.80(2 \mathrm{H}$, $d, J=8.5 \mathrm{~Hz}), 9.86(1 \mathrm{H}, s)$. Positive to the phenol reagent and 2,4-dinitrophenylhydrazine.

The structure of $\mathrm{D}$ was identical with $p$-hydroxybenzaldehyde.

\section{Identification of compound $\dot{E}$}

Compound $\mathrm{E}$ was obtained as methyl ester (E-Me) after treatment with diazomethane. Yield $6.4 \mathrm{mg} / \mathrm{kg}$ fresh root. $[\alpha]_{\mathrm{D}}^{20}+2.8^{\circ}(\mathrm{EtOH} ; c$ 0.92). EI-MS $m / z$ (rel. int.): $310.2507[\mathrm{M}]^{+}\left(\mathrm{C}_{19} \mathrm{H}_{34} \mathrm{O}_{3}\right)(4), 292\left[\mathrm{M}-\mathrm{H}_{2} \mathrm{O}\right]^{+}(21)$, 279 (3), $239.1636\left(\mathrm{C}_{14} \mathrm{H}_{23} \mathrm{O}_{3}\right)(4), 207.1399\left(\mathrm{C}_{13} \mathrm{H}_{19} \mathrm{O}_{2}\right)$ (15), $99.0810\left(\mathrm{C}_{6} \mathrm{H}_{11} \mathrm{O}\right)(100), 71.0859\left(\mathrm{C}_{5} \mathrm{H}_{11}\right)(58) .{ }^{1} \mathrm{H}-\mathrm{NMR}(270$ $\left.\mathrm{MHz}, \mathrm{CDCl}_{3}, \mathrm{TMS}\right): \delta 0.89(3 \mathrm{H}, t, J=6.6 \mathrm{~Hz}), 2.17(2 \mathrm{H}$, $m), 2.30(2 \mathrm{H}, t, J=7.5 \mathrm{~Hz}), 3.67(3 \mathrm{H}, s), 4.16(1 \mathrm{H}, m), 5.43$ $(1 \mathrm{H}, d t, J=11.0$ and $7.7 \mathrm{~Hz}), 5.67(1 \mathrm{H}, d d, J=15.4$ and $7.0 \mathrm{~Hz}), 5.97(1 \mathrm{H}, d d, J=11.0$ and $11.0 \mathrm{~Hz}), 6.49(1 \mathrm{H}, d d t$, $J=15.0,11.0$ and $1.1 \mathrm{~Hz}$ ).

The molecular formula was determined to be $\mathrm{C}_{19} \mathrm{H}_{34} \mathrm{O}_{3}\left([\mathrm{M}]^{+}\right.$calcd 310.2507$)$. The EI-MS indicated the typical fragmentation pattern of fatty acids and the presence of a hydroxyl group at $m / z 292$. In the ${ }^{1} \mathrm{H}-\mathrm{NMR}$, the signals at $\delta 2.17(\mathrm{~m})$ and $4.16(\mathrm{~m})$, the double triplet at $\delta 5.43$, the double doublets at $\delta 5.67$ and 5.97 and the doublet of doublets of triplets at $\delta 6.49$ explained a 1-hydroxy-2E,4Z-hexadiene moiety $\left(-\mathrm{CH}_{2}-\mathrm{CH}=\mathrm{CH}-\mathrm{CH}=\mathrm{CH}-\mathrm{HCOH}-\right)$. The singlet at $\delta 3.67$ and the triplet at $\delta 2.30$ were assigned to a methyl ester $\left(-\mathrm{CH}_{2}-\mathrm{CH}_{2}-\mathrm{CO}-\mathrm{O}-\mathrm{CH}_{3}\right)$, and the triplet at 0.89 assigned to a terminal ethyl group $\left(-\mathrm{CH}_{2}-\mathrm{CH}_{3}\right)$. These data suggested a linoleic acid derivative containing a hydroxyl group and two conjugated double bonds. In the EI-HR-MS study, the diagnostic fragments at $m / z 239.1636\left(\mathrm{C}_{14} \mathrm{H}_{23} \mathrm{O}_{3}\right.$; calcd 239.1646), $207.1399\left(\mathrm{C}_{13} \mathrm{H}_{19} \mathrm{O}_{2}\right.$; calcd 207.1385), $99.0810\left(\mathrm{C}_{6} \mathrm{H}_{11} \mathrm{O}\right.$; calcd 99.0810), $71.0859\left(\mathrm{C}_{5} \mathrm{H}_{11}\right.$; calcd $71.0860)$ corroborated a hydroxyl group at $\mathrm{C}-13$ and two double bonds at C-9 and C-11. From these data the structure of compound E-Me was determined as methyl (13S)-13-hydroxy-(9Z,11E)-9,11-octadecadienoate. Therefore compound E was identified as (13S)-13hydroxy-(9Z,11E)-9,11-octadecadienoic acid. The value of optical rotation $\left(+2.8^{\circ}\right)$ which was lower than published value ${ }^{8)}\left(+11.0^{\circ}\right)$ of methyl $13 S$-hydroxylinoleate may be caused by purity.

\section{Identification of compound $F$}

Compound $\mathrm{F}$ was obtained as methyl ester (F-Me) after methylation with diazomethane. Yield $3.1 \mathrm{mg} / \mathrm{kg}$ fresh root. $[\alpha]_{\mathrm{D}}^{20}+3.6^{\circ}(\mathrm{EtOH} ; c 0.22)$. EI-MS $m / z$ (rel. int.): $310.2504[\mathrm{M}]^{+}\left(\mathrm{C}_{19} \mathrm{H}_{34} \mathrm{O}_{3}\right)(5), 292\left[\mathrm{M}-\mathrm{H}_{2} \mathrm{O}\right]^{+}(19)$, 279 (3), $239.1642\left(\mathrm{C}_{14} \mathrm{H}_{23} \mathrm{O}_{3}\right)(3), 207.1405\left(\mathrm{C}_{13} \mathrm{H}_{19} \mathrm{O}_{2}\right)$ (14), $99.0814\left(\mathrm{C}_{6} \mathrm{H}_{1.1} \mathrm{O}\right)(100), 71.0862\left(\mathrm{C}_{5} \mathrm{H}_{11}\right)(53) .{ }^{1} \mathrm{H}-\mathrm{NMR}(270$ $\left.\mathrm{MHz}, \mathrm{CDCl}_{3}, \mathrm{TMS}\right): \delta 0.89(3 \mathrm{H}, \mathrm{t}, J=6.8 \mathrm{~Hz}), 2.07(2 \mathrm{H}$, $m), 2.30(2 \mathrm{H}, t, J=7.5 \mathrm{~Hz}), 3.67(3 \mathrm{H}, s), 4.11(1 \mathrm{H}, m), 5.58$ $(1 \mathrm{H}, d d, J=15.0$ and $7.0 \mathrm{~Hz}), 5.68(1 \mathrm{H}, d t, J=14.7$ and $10.5 \mathrm{~Hz}), 6.01(1 \mathrm{H}, d d, J=14.7$ and $10.5 \mathrm{~Hz}), 6.17(1 \mathrm{H}$, $d d d, J=14.7,10.3$ and $0.7 \mathrm{~Hz}$ ).

The MS of F-Me was very similar to that of E-Me and gave the molecular formula was as $\mathrm{C}_{19} \mathrm{H}_{34} \mathrm{O}_{3}$ (calcd 310.2507), suggesting an isomer of E-Me as structure of F-Me. In the ${ }^{1} \mathrm{H}$-NMR study, the multiplet at $\delta 2.07$ and 4.11 , the double doublet at $\delta 5.58$ and 6.01 , the double triplet at $\delta 5.68$ and the doublet of doublets of doublets at $\delta 6.17$ demonstrated a 1 -hydroxy-2E,4E-hexadiene moiety. These data suggested that the structure of F-Me was methyl 13-hydroxy-(9E,11E)-9,11-octadecadienoate, the trans isomer at a C-9 double bond of E-Me. Consequently compound $\mathrm{F}$ was 13-hydroxy-(9E,11E)-9,11octadecadienoic acid.

\section{Identification of compound $G$}

Compound $G$ was obtained as methyl ester (G-Me) after methylation with diazomethane. Yield $5.7 \mathrm{mg} / \mathrm{kg}$ fresh root. $[\alpha]_{\mathrm{D}}^{20}+3.4^{\circ}(\mathrm{EtOH} ; c 0.53)$. EI-MS $m / z$ (rel. int.): $310.2503[\mathrm{M}]^{+}\left(\mathrm{C}_{19} \mathrm{H}_{34} \mathrm{O}_{3}\right)(5), 292\left[\mathrm{M}-\mathrm{H}_{2} \mathrm{O}\right]^{+}(18)$, 279 (4), $185.1181\left(\mathrm{C}_{10} \mathrm{H}_{17} \mathrm{O}_{3}\right)(34), 155.1081\left(\mathrm{C}_{19} \mathrm{H}_{15} \mathrm{O}_{2}\right)(17)$, $125.0938\left(\mathrm{C}_{8} \mathrm{H}_{13} \mathrm{O}\right)$ (35), $55.0541\left(\mathrm{C}_{4} \mathrm{H}_{7}\right)$ (100). ${ }^{1} \mathrm{H}-\mathrm{NMR}$ $\left(270 \mathrm{MHz}_{2} \mathrm{CDCl}_{3}, \mathrm{TMS}\right): \delta 0.89(3 \mathrm{H}, t, J=6.8 \mathrm{~Hz}), 2.18$ $(2 \mathrm{H}, m), 2.30(2 \mathrm{H}, t, J=7.5 \mathrm{~Hz}), 3.67(3 \mathrm{H}, s), 4.15(1 \mathrm{H}, m)$, $5.45(1 \mathrm{H}, d t, J=10.6$ and $7.0 \mathrm{~Hz}), 5.66(1 \mathrm{H}, d d, J=15.2$ and $7.0 \mathrm{~Hz}), 5.97(1 \mathrm{H}, d d, J=11.2$ and $11.2 \mathrm{~Hz}), 6.49(1 \mathrm{H}$, $d d t, J=15.2,11.2$ and $1.1 \mathrm{~Hz}$ ).

The molecular formula was determined to be $\mathrm{C}_{19} \mathrm{H}_{34} \mathrm{O}_{3}$ (calcd 310.2507). The ${ }^{1} \mathrm{H}-\mathrm{NMR}$ spectrum was in good agreement with that of E-Me and suggested that G-Me was a isomer of E-Me containing the same partial structures, a 1-hydroxy- $2 E, 4 Z$-hexadiene moiety, with E-Me. The EI-MS of G-Me gave the typical fragment ions at $m / z 185,155,125$ and 55 , which formulas were determined to be $\mathrm{C}_{10} \mathrm{H}_{17} \mathrm{O}_{3}$ (calcd 185.1178), $\mathrm{C}_{9} \mathrm{H}_{15} \mathrm{O}_{2}$ (calcd 155.1072), $\mathrm{C}_{8} \mathrm{H}_{13} \mathrm{O}$ (calcd 125.0966) and $\mathrm{C}_{4} \mathrm{H}_{7}$ (calcd 55.0547) by HR-MS measurements. These fragment ions indicated a hydroxy group at C-9 and the double bonds at C-10 and C-12. According to the optical rotation ${ }^{6,8)}$ the configuration at C-9 was determined to be $S$. From these data compounds G-Me and G were identified as methyl 
(9S)-9-hydroxy-(10E,12Z)-10,12-octadecadienoate and (9S)-9-hydroxy-(10E,12Z)-10,12-octadecadienoic acid, respectively.

\section{Identification of compound $\boldsymbol{H}$}

Compound $\mathrm{H}$ was isolated as methyl ester (H-Me) after methylation with diazomethane. Yield $2.8 \mathrm{mg} / \mathrm{kg}$ fresh root. $[\alpha]_{D}^{20}+2.4^{\circ}(\mathrm{EtOH} ; c$ 0.42). EI-MS $m / z$ (rel. int.): 310.2504 [M] ${ }^{+}\left(\mathrm{C}_{19} \mathrm{H}_{34} \mathrm{O}_{3}\right)(4), 292\left[\mathrm{M}-\mathrm{H}_{2} \mathrm{O}\right]^{+}(13)$, 279 (4), $185.1172\left(\mathrm{C}_{10} \mathrm{H}_{17} \mathrm{O}_{3}\right)(27), 155.1073\left(\mathrm{C}_{9} \mathrm{H}_{15} \mathrm{O}_{2}\right)$ (15), $125.0977\left(\mathrm{C}_{8} \mathrm{H}_{13} \mathrm{O}\right)(30), 55.0546\left(\mathrm{C}_{4} \mathrm{H}_{17}\right)(100) .{ }^{1} \mathrm{H}-\mathrm{NMR}$ $\left(270 \mathrm{MHz}, \mathrm{CDCl}_{3}, \mathrm{TMS}\right): \delta 0.89(3 \mathrm{H}, t, J=6.8 \mathrm{~Hz}), 2.07$ $(2 \mathrm{H}, m), 2.30(2 \mathrm{H}, t, J=7.5 \mathrm{~Hz}), 3.66(3 \mathrm{H}, s), 4.10(1 \mathrm{H}, m)$, $5.57(1 \mathrm{H}, d d, J=15.3$ and $7.2 \mathrm{~Hz}), 5.70(1 \mathrm{H}, d d, J=15.0$ and $7.0 \mathrm{~Hz}), 6.02(1 \mathrm{H}, d d t, J=15.1,10.3$ and $1.1 \mathrm{~Hz}), 6.17$ $(1 \mathrm{H}, d d d, J=15.0,10.3$ and $0.7 \mathrm{~Hz})$.

The EI-MS of H-Me agreed with that of G-Me and gave the molecular formula as $\mathrm{C}_{19} \mathrm{H}_{34} \mathrm{O}_{3}$ (calcd 310.2507), suggesting an isomer of G-Me as structure of $\mathrm{H}-\mathrm{Me}$. In the ${ }^{1} \mathrm{H}$-NMR spectrum, the multiplet at $\delta 2.07$ and 4.10 , the double doublet at $\delta 5.57$ and 5.70 , the doublet of doublets of triplets at $\delta 6.02$ and the doublet of doublets of doublets at $\delta 6.17$ exhibited a 1-hydroxy-2E,4Ehexadiene moiety. Thus the structure of $\mathrm{H}-\mathrm{Me}$ and $\mathrm{H}$ were characterized as methyl 9-hydroxy-(10E,12E)-10, 12-octadecadienoate and 9-hydroxy-(10E,12E)-10,12octadecadienoic acid, respectively.

\section{Identification of compound I}

Compound I was obtained as methyl ester (I-Me) after methylation with diazomethane. Yield $2.4 \mathrm{mg} / \mathrm{kg}$ fresh root. EI-MS $m / z$ (rel.int.): $152\left[\mathrm{MM}^{+}\right.$(38), 121 (100), 93 (24). ${ }^{1} \mathrm{H}-\mathrm{NMR}\left(270 \mathrm{MHz}, \mathrm{CDCl}_{3}, \mathrm{TMS}\right): \delta 3.89(3 \mathrm{H}, s)$, $5.32(1 \mathrm{H}, b r . s), 6.85(2 \mathrm{H}, d, J=9.0 \mathrm{~Hz}), 7.96(2 \mathrm{H}, d, J=9.0$ $\mathrm{Hz}$ ). Positive to the phenol reagent.

The structures of I-Me and I were determined to be methyl $p$-hydroxybenzoate and $p$-hydroxybenzoic acid, respectively.

\section{Identification of compound $J$}

Compound J was isolated as methyl ester (J-Me) after methylation with diazomethane. Yield $0.4 \mathrm{mg} / \mathrm{kg}$ fresh root. EI-MS $m / z$ (rel.int.): $182[\mathrm{M}]^{+}$(53), 167 (6), 151 (100), 123 (21). ${ }^{1} \mathrm{H}-\mathrm{NMR}\left(270 \mathrm{MHz}, \mathrm{CDCl}_{3}, \mathrm{TMS}\right): \delta 3.89$ $(3 \mathrm{H}, s), 3.95(3 \mathrm{H}, s), 5.99(1 \mathrm{H}, s), 6.94(1 \mathrm{H}, d, J=8.0 \mathrm{~Hz})$, $7.55(1 \mathrm{H}, d, J=1.8 \mathrm{~Hz}), 7.64(1 \mathrm{H}, d d, J=8.0$ and $1.8 \mathrm{~Hz})$. Positive to the phenol reagent.

These data showed the structure J-Me and $\mathrm{J}$ to be methyl vanillate and vanillic acid, respectively.

\section{Identification of compound $K$}

Compound $\mathrm{K}$ was isolated as dimethyl ester (K-Me). Yield $1.3 \mathrm{mg} / \mathrm{kg}$ fresh root. EI-MS $m / z$ (rel.int.): $217.1400[\mathrm{MH}]^{+}\left(\mathrm{C}_{11} \mathrm{H}_{21} \mathrm{O}_{4}\right)(0.5), 199.1331[\mathrm{M}-\mathrm{OH}]^{+}$ $\begin{array}{llllll}\left(\mathrm{C}_{11} \mathrm{H}_{19} \mathrm{O}_{3}\right) & (0.5), & 185.1180 & \left(\mathrm{C}_{10} \mathrm{H}_{17} \mathrm{O}_{3}\right) & (27), & 171.1023\end{array}$ $\left(\mathrm{C}_{9} \mathrm{H}_{15} \mathrm{O}_{3}\right)$ (12), 152 (43), 74 (100). FI-MS $m / z$ (rel.int.): 217
$[\mathrm{MH}]+{ }^{+}(100) .{ }^{1} \mathrm{H}-\mathrm{NMR}\left(270 \mathrm{MHz}, \mathrm{CDCl}_{3}, \mathrm{TMS}\right): \delta 1.32$ $(6 \mathrm{H}, m), 1.62(4 \mathrm{H}, m), 2.30(4 \mathrm{H}, t, J=7.5 \mathrm{~Hz}), 3.67(6 \mathrm{H}, s)$.

The EI-MS and FI-MS gave the molecular ion peak at $m / z \quad 217$ and suggested the molecular formula as $\mathrm{C}_{11} \mathrm{H}_{20} \mathrm{O}_{4}$ (found 217.1400; calcd 217.1440). In the ${ }^{1} \mathrm{H}$ NMR investigation the signals at $\delta 1.32,1.62,2.30$ and 3.67 demonstrated the presence of two methyl ester moieties $\left(-\mathrm{CH}_{2}-\mathrm{CH}_{2}-\mathrm{COOCH}_{3}\right)$ and tree methylenes $\left(-\mathrm{CH}_{2}-\right)$. Therefore the structures of $\mathrm{K}$ and $\mathrm{K}-\mathrm{Me}$ were identified as dimethyl nonandioate and nonandioic acid (azelaic acid), respectively.

Contents of unsaturated hydroxy fatty acids

Contents of four unsaturated hydroxy fatty acids in stocks and tomatoes were shown in Table 2. No differences can be observed between the contents of both plants.

\section{Fungitoxic activity of alkaloids}

Five alkaloids ${ }^{7)}$ (Fig. 3) described below inhibited the growth of $F$. oxysporum $\mathrm{f}$. sp. radicis-lycopersici at the amount of more than $20 \mu \mathrm{g}$ per one spot on the TLC plate: $5 \alpha$-tomatidan-3-one (2), (23S)-23-acetoxysoladulcidine (4), (23S,25S)-23-acetoxy- $5 \alpha, 22 \alpha \mathrm{N}$-spirosolan-3 $\beta$-ol (5), 22 , 26 -epimino-16 $\beta, 23$-epoxy-23 $\alpha$-ethoxy- $5 \alpha, 25 \alpha$ H-cholest-
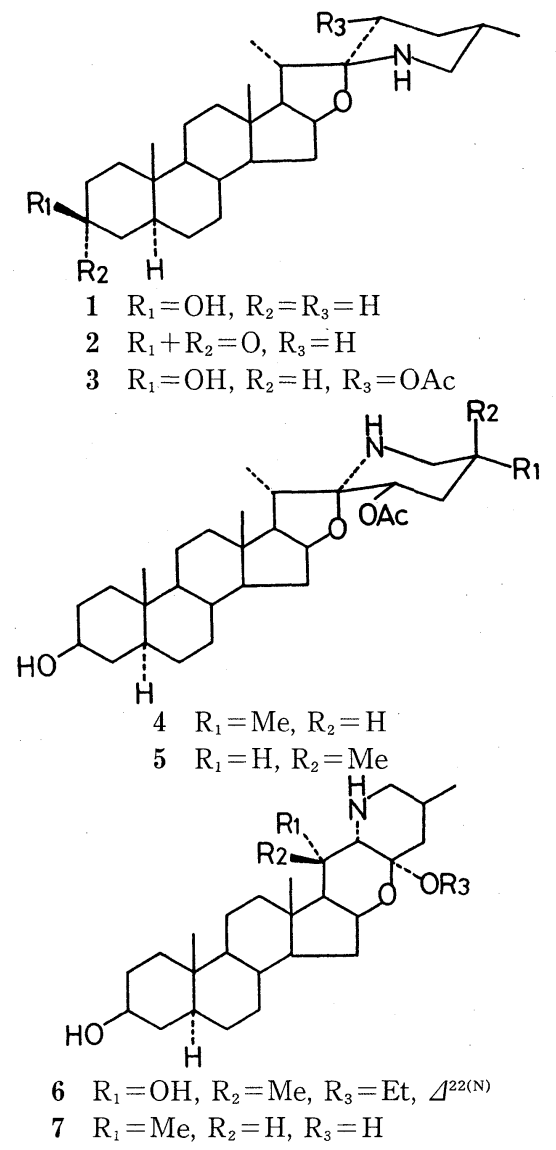

Fig. 3. Alkaloids from tomato stock.

Table 2. Contents of unsaturated hydroxy fatty acids ( $\mu \mathrm{g} / \mathrm{g}$ fresh roots)

\begin{tabular}{lcccc}
\hline \hline & $13-\mathrm{OH}(Z, E)$ & $13-\mathrm{OH}(E, E)$ & $9-\mathrm{OH}(E, Z)$ & $9-\mathrm{OH}(E, E)$ \\
\hline Stock & 5.2 & 3.8 & 3.8 & 2.2 \\
Tomato & 3.2 & 1.6 & 4.8 & 2.6 \\
\hline
\end{tabular}


$22(\mathrm{~N})$-ene- $3 \beta, 20 \alpha$-diol (6),22,26-epimino-16 $\beta, 23$-epoxy- $5 \alpha$, $22 \beta \mathrm{H}, 25 \alpha \mathrm{H}$-cholestane- $3 \beta, 23 \alpha$-diol (7). Tomatidine (1) and (23R)-23-acetoxytomatidine (3) (Fig. 3) had no fungitoxic activity at the amount of $250 \mu \mathrm{g}$ per spot.

\section{DISCUSSION}

In order to reveal the resistance mechanisms of stocks against the soil-borne diseases, the relationship between stocks and tomatoes in fungitoxic activity was investigated (Fig. 1). The ether and ethyl acetate extracts from stocks showed a stronger inhibitory effect than that from tomatoes against $F$. oxysporum f. sp. lycopersici, $F$. oxysporum f. sp. radicis-lycopersici, P. lycopersici and $V$. dahliae. These data suggested that some fungitoxic compounds partly participate in resistance.

The ether extracts of tomato stocks grown were investigated. Five phenolic compounds (vanillin, syringaldehyde, $p$-hydroxybenzaldehyde, $p$-hydroxybenzoic acid and vanillic acid) were isolated and identified. These phenolic compounds have been isolated from many higher plants and well known as fungitoxic compounds. Because of this universality, these phenolic compounds seem to make small contributions to specific resistance of the stocks against soil-borne diseases.

Four hydroxy linoleic acids would be generated by reduction from hydroperoxides. Lipoxygenase of soybean and tomato also converted linoleic acid to $13 S$ hydroperoxide $^{2)}$ and 9S-hydroperoxide ${ }^{6)}$, respectively. Hydroxy linoleic acids $\mathrm{E}$ and $\mathrm{G}$ were isolated as fungitoxic compounds from resistant cultivar of rice plant ${ }^{4)}$ and tomato inoculated with Phytophthora parasitica and Verticillium albo-atrum ${ }^{9)}$. These suggested the relationship between resistance against pathogen and hydroxy linoleic acids. But no differences in contents of four hydroxy linoleic acids can be observed between stock and tomato in our data. Azelaic acid was also isolated as fungitoxic compounds from rice plant ${ }^{5}$. Steroidal alkaloids previously isolated from ether and ethyl acetate soluble fraction of tomato stocks ${ }^{7)}$ may play an important role in resistance of tomato stocks because of the high antifungal activity and high content of basic compounds in the stock. The survey of the alkaloids in tomato has not been done, but the presence in the stock may be specific since these alkaloids except tomatidine have never been isolated in spite of many investigations of tomato. Antifungal sesquiterpene, such as solavetivone, was not present. This is different from an eggplant (Solanum), though both plants belong to the same family, Solanaceae.

\section{Literature cited}

1. Coxon, D.T., Price, K.R., Howard, B., Osman, S.F., Kalan, E.B. and Zacharius, R.M. (1974). Two new vetispirane derivatives: stress metabolites from potato (Solanum tuberosum) tubers. Tetrahedron Lett. : 29212924.

2. Hamberg, M. (1971). Steric analysis of hydroperoxides formed by lipoxygenase oxygenation of linoleic acid. Anal. Biochem. $43: 515-526$.

3. Homans, A.L. and Fuchs, A. (1970). Direct bioautography on thin-layer chromatograms as a method for detecting fungitoxic substances. J. Chromatogr. 51: 327-329.

4. Kato, T., Yamaguchi, Y., Hirano, T., Yokoyama, T., Uyehara, T., Namai, T., Yamanaka, S. and Harada, N. (1984). Unsaturated hydroxy fatty acids, the self defensive substances in rice plant against rice blast disease. Chem. Lett. 409-412.

5. Kato, T., Yamaguchi, Y., Uyehara, T. and Namai, T. (1986). Oxidized unsaturated fatty acids related to resistance to rice blast disease. Kagaku to Seibutu 24 : 183-188 (in Japanese).

6. Matthew, J.A., Chan, H.W.S. and Galliard, T. (1977). A simple method for the preparation of pure 9-Dhydroperoxide of linoleic acid and methyl linoleate based on the positional specificity of lipoxygenase in tomato fruit. Lipids $12: 324-326$.

7. Nagaoka, T., Yoshihara, T., Ohra, J. and Sakamura, S. (1993). Steroidal alkaloids from roots of tomato stock. Phytochemistry $34: 1153-1157$.

8. Patee, H.E. and Singleton, J.A. (1979). Evidence of enzymic production of 9-hydroperoxy-trans-10,cis-12octadecadienoic acid by peanut lipoxygenase. J. Agric. Food Chem. 27 : 216-220.

9. Vernenghi, A., Einhorn, J., Kunesch, G., Maloses, C., Ramiandrasoa, F. and Revisé, A. (1986). Phyto-alexins and defense reactions of tomato to infection by Phytophthora parasitica and Verticillium albo-atrum. Can. J. Bot. 64 : 973-982.

10. Yoshihara, T., Hagihara, Y., Nagaoka, T., Chiba, S. and Sakamura, S. (1988). Fungitoxic compounds from the roots of the eggplant stock. Ann. Phytopathol. Soc. Jpn. $54: 453-459$.

\section{和 文 摘 要}

長岡俊徳・大羅順子・吉原照彦・坂村貞雄：トマト台木根加ら の抗菌物質

トマト台木植物(品種：耐病新交 1 号)の根部から抗菌物質と して 4 種の不飽和ヒドロキシ脂肪酸 $[(13 S)-13$-ヒドロキシ- $(9 Z$ ， $11 E)-9,11$-オクタデカジエン酸，13-ヒドロキシ-(9E,11E)-9,11オクタデカジエン酸, (9S)-9-ヒドロキシ-(10E,12Z)-10,12-オク タデカジエン酸, 9-ヒドロキシ-(10E,12E)-10,12-オクタデカジエ ン酸］と 5 種のフェノール化合物(バニリン, シリンガアルデヒ ド, $p$-ヒドロキシベンズアルデヒド, $p$-ヒドロキシ安息香酸, バ ニリン酸), 一種のジカルボン酸(アゼライン酸), 一種のキノン (2,6-ジメトキシ- $p$-ベンゾキノン)を単離し, 化学構造を決定し た。トマト台木の土壤病害抵抗性に関与する抗菌物質は植物に 普遍的に存在するこれらの化合物ではなく, 既報のアルカロイ ドであることを示唆した。 